\title{
Community level mechanisms and strategies for managing sustainable water supply systems: lessons from Bongo district of northern Ghana
}

\begin{abstract}
The study examined the nature of community level mechanisms and strategies for the management of sustainable water supply systems in the Bongo District through the lens of the structural functional theory perspective. The study employed a multiple method approach with a total of 167 respondents through face-to-face interviews and household survey. The evidence suggests that community level participation in water resource systems management is seen in decision-making, rule formulation and general day-to-day management via regular community meetings and consultation with community members, elders and opinion leaders. Beneficiaries of water systems were solely in-charge of the operations and maintenance of water systems in the community with very limited government support and involvement. The evidence also points to women playing a major role in local level management of water resource systems. Interestingly, traditional cultural practices (e.g taboos) as well as social norms previously used in the management of water resource systems has gradually become obsolete and ineffective with the advent of formal education and Christianity in the local communities.
\end{abstract}

Keywords Community level mechanisms, water supply systems, local management, Ghana

\section{Introduction}

This paper aims to examine the nature of community level mechanisms and strategies for managing sustainable water supply systems in the Bongo District through the lens of the structural functional theory perspective. The paper specifically focuses on how the integration of community level participation and decentralization concepts of local governance in the management of water resources can optimize sustainable water supply to households in rural Ghana by drawing lessons from Bongo district of Ghana. Fundamentally, a proper approach in the management of community level water resource systems in the long-term ensures sustainable water supply to households (Yeleliere et al. 2018; Kelly et al. 2017) and remain an important component of bringing sustainability to water utilisation (Opare 2011; Distanont et al. 2017). Managing sustainable water supply successfully at the local level means operating and maintaining a water supply system on a day-to-day basis so that the system continuous to work and supply water as planned (Msuya and Lalika 2018; Okpara et al. 2018). In development discourse, sustainable water supply influences development as well as promote better health and living conditions which explicitly impact on social, economic and community development (Tantoh and Simatele 2018; Knüppea and Meissner 2016; Apipalakul et al. 2015). In general, sustainable livelihood is enhanced and this brings together the thinking and practice of poverty reduction strategies through community level intervention approach. Most importantly, sustainable water supply promotes economic growth and development and peoples' interconnectedness with the natural environment is key to human sustenance and livelihoods (Fonjong et al. 2004; Kelly et al. 2017; Tantoh and Simatele 2018). Though environmental and natural resources such as water, forest and land have been recognised as life support systems, there is a total neglect of the importance of these resources, especially in less developed countries across the sub-Saharan African region (Tantoh and Simatele 2018; Knüppea and Meissner 2016; Ahadzie et al. 2005). 
Securing safe and reliable water for all has become a major challenge that undermines sustainable development in less developed and emerging economies in Sub-Sahara Africa (Foli et al. 2018; Tantoh and Simatele 2018). It is estimated that all over the world, more than one billion people still do not have access to safe water and at least five million deaths per year are attributable to water borne diseases according to the World Health Organisation in 2010. It has also been estimated that about 884 million people continue to experience challenges in accessing drinking water from improved sources (WHO 2010; UNICEF 2010). Indeed, SubSaharan Africa, the world's poorest region is largely affected and has fallen behind in progress towards achieving the Millennium Development Goals (MDGs) and now the Sustainable Development Goals (Kelly et al. 2017; Rahm et al. 2006). Even though, Ghana has seen significant improvement in water access since the late 1990s, the Water and Sanitation Sector Monitoring Platform (2010) report suggests that about 23.4\% of the rural population lack access to portable water. Similarly, the Community Water and Sanitation Agency (2009) notes that there is acute shortage of portable water in Ghana, especially in the Northern Region, where about $40 \%$ of the population rely on unimproved sources of drinking water. In this context, indigenous community level management of water supply systems has increasingly become necessary and an important part of the national program for sustainable water supply and development (Yeleliere et al. 2018; Foli et al. 2018; Opare 2011). As part of the guiding principles adopted under the New Delhi Consultation in 1990, a number of international development organisations have drawn policy-makers attention to strengthen local institutions to implement sustainable water management programs and practices (World Bank 2004).

Over the last decade, the community water and sanitation agency (CWSA) has expanded its coverage in all ten regions of Ghana, with community level representation across the country. As part of the decentralisation agenda, district water and sanitation teams (DWSTs) were established in 134 districts as well as water and sanitation committees (WATSANs). On the one hand, informal institutions such as 'taboos' in Africa and, particularly Ghana has offered some effective opportunities in local resource management and conservation. The notion of 'taboos' are grounded on mythical beliefs which restrict or prohibit a practice (Osei-Tutu 2018; Nukunya 2003). These behavioural guidelines has played useful role in natural resource conservation and management in Ghana (Osei-Tutu 2018), especially before and immediately after Ghana's independence. In addition, community elders and opinion leaders were also entrusted with the responsibilities of managing water supply systems at the community level. Ostrom (2005) suggest that there is the need for water to be managed based on clearly defined boundaries and with the principle of graduated sanctions in order to ensure water supply sustainability. Indeed, community participation in the monitoring and management of water resource systems has been identified as an important concept in supporting sustainable water management in Ghana and other less developed countries across sub-Sahara Africa (Nastar et al. 2018; Tantoh and Simatele 2018; Knüppea and Meissner 2016).

The World Water Council (2003) report identified poor local community water management as the underlining cause of unsustainable water supply to households in developing countries. As the world's population continues to grow, water resources are constantly under siege and as such freshwater scarcity and its decreasing quality will adversely affect the health and livelihood of the population (Yeleliere et al. 2018). The Water Research Institute, an agency under the Centre for Scientific and Industrial Research (WRI-CSIR) (2010) asserted that though Ghana appears to have abundant water resources, the country may experience water-stressed by 2025. Therefore, a better approach to water resource management is urgent if the country is to avoid water-stress (WRI-CSIR, 2010). We contend here that a more community-oriented management approach is needed to ensure sustainable water supply. Primarily, a community level focused water management system acknowledges stakeholder 
participation (Adams et al. 2018), community ownership (Distanont et al. 2018), monitoring and enforcement of local regulations (Franzen et al. 2015) and community level funding support model (Rusca and Schwartz 2018; Harvey and Reed 2007).

The community level management concept gained global recognition within the international development literature, particularly in natural resource conservation and management (Adams et al. 2018; Osei-Tutu, 2018). The underpinning principles of the community management concept is based on the assumption that beneficiaries of natural resources (water) have an important role in its development as well as the obligation for its operations and maintenance (Cavalcanti et al. 2013; Harvey and Reed 2007). In fulfilling these responsibilities, community water committees must ensure the management and sustenance of water supply systems. Essentially, several studies has pointed to mismanagement, inadequate funding and lack of stakeholder participation as major factors responsible for the lack of sustainable water supply systems in Ghana (e.g. Acheampong 2011; WRI-CSIR 2010), and likewise many less developed countries in sub-Sahara Africa. Of particular interest is the work of Acheampong (2011) who argue that the lack of fiscal discipline and maintenance, poor water billing system are detrimental to water systems' management at the community and national levels in developing countries. This paper therefore seeks to contribute to the community level water management policy debate within the natural resource management literature by examining the nature of community level mechanisms and strategies for managing sustainable water supply systems in the Bongo District through the lens of the structural functional theory perspective.

\section{The structural functional theory}

The structural functional theory in sociology underscores the power of culture, values and norms as underpinning tools for the management of natural resources, especially in culturalembedded societies (Osei-Tutu 2018; Giddens 1984). The structural functional theory draws support from the theory of structuration, which argues that individuals' actions are shaped and constrained by social structures (Barley and Tolbert 1997; Giddens 1984). In natural resources management literature, various rules, legislations and practices have been established by resource users that serve to constrain the respective authorised actions in order to ensure sustainable utilisation of natural resources (Franzen et al. 2015; Cleaver et al. 2005). Specifically, formal and informal rules governing resource usage specify how much units of a resource an individual can appropriate at what time and where (Cleaver et al. 2005). Ostrom (1990) argue that if everyone follows these legislations, common pool resources will be allocated more efficiently and in a sustainable manner. According to the UNDP (2007), there is a considerable agreement in policy making cycles about the need for appropriate water legislations as the framework for effective sustainable water delivery. In effect, legislation as a tool of ensuring sustainable water supply is essential for overcoming shortcomings of water inaccessibility and as a tool for meeting the sustainable development goals (Adam and Smiley 2018). Frederickson (1999) in explaining human behaviour suggests that this should not only encompass a focus on formal rules but also on the functions of societal norms, belief systems and values as well as informal arrangements in addition to imposition of sanctions. Wong (2007) highlights the importance of sanctions, whereas Alkire and Deneulin (2000) hypothesize that individuals are simply law abiding because of the fear of being sanctioned. There is the need to consider a wider variety of societal values, indigenous knowledge and perspectives in a collaborative decision-making and management processes, which include participatory forms of modelling and planning in water resource management (Osei-Tutu 2018; Von Korff et al. 2012; Butterworth et al. 2010). 
The World Bank (1993) suggests that participatory approach supports sustainable natural resource management and promote a sense of ownership of the resource at the community level. Community level involvement in water resource management tends to ensure greater success (Tantoh and Simatele 2018; Distanont et al. 2017; Knüppea and Meissner 2016; World Bank 2004). Community participation may affect policy formulation and provide alternative designs, investment choices and management decisions that affect communities and in the long-run improve incentives for cost recovery and service quality (Adams et al. 2018; Apipalakul et al. 2015; World Bank 2004). Drawing from the theory of Feminist Political Ecology, Cleaver (2002) assert that to ensure sustainable water supply, greater attention should be paid to the role of women. Similarly, Adams et al. (2018) argued that access to water is a more demanding need for women, because of their domestic tasks responsibilities. Thus, women participation in water governance remains important. The World Bank (1993) found that women were responsible for the successes and sustainability of water supply projects in many developing economies. Despite women representing the major water user group in general, men remain at the forefront of water resource management issues, which cast dark shadows on sustainable water supply in Sub-Sahara Africa (Zwarteveen 1997), where women are likely to be underrepresented in the decision-making processes in relation to water management (Adams et al. 2018).

\section{Literature Review}

Stakeholder engagement and participation in local water management has progressively remain an important element in natural resource management, which is grounded on two underpinning principles (Franzén et al. 2015). First, stakeholder participation can strengthen decentralisation processes to enhance democracy and transparency in natural resource management. Second, stakeholder participation in water management could lead to capacity-building and learning and the effective implementation of policies at the community level (Franzén et al. 2015; Distanont et al. 2017; Tantoh and Simatele 2018) which directly support water sustainability. Several dimensions of stakeholder participation has been categorised in the management literature for measuring the degree of stakeholder participation. The Water Framework Directive promotes water governance by categorising stakeholder participation into 'passive' and 'active', where the latter represents a more integrated and collaborative form of participation, whereas the former is limited to information access and consultation (Franzén et al. 2015). The literature lend significant support to the adoption of active stakeholder participation in local water management to ensure sustainable water supply (Harvey and Reed 2007).

The management of scarce resources to meet developmental goals and aspirations has been a major concern among policy-makers in developing and developed countries. Water resources are scarce and where available they must be prudently and effectively managed amid varying needs and goals (Kelly et al., 2017). The main challenge of government is how to increase local participation that will ensure a longer span water supply sustainability. Importantly, an effective planned water management strategy should outline the full participation of local communities to enhance the conservation of natural resources at the community level (Adams et al. 2018; IRC 1993). Implicitly or explicitly, indigenous institutions and indigenous knowledge has proven to underpin natural resource management activities and sustainability (Foli et al. 2018; World Bank, 2004). Therefore, through community participation and empowerment in decision-making, natural resources may be effectively managed to serve the needs of the community (Distanont et al. 2018).

On the one hand, decentralisation of water resources management is an important concept that support service delivery and encourage power transfer from centralised 
government to the local communities (World Bank, 1993), which support community level engagement and involvement (Cavalcanti et al. 2013). Over the years, the centralised system of governance has been criticised on the basis of high administrative cost and low efficiency in water supply (Wong, 2007) and lack of community level engagement and involvement (Dare and Venot 2017). It is within this context that the concept of decentralisation has recently become a fashion of modern governance system. Indeed, decentralisation reduce centralised control system and minimize power held by corrupt centralised governments, promote the use of indigenous knowledge, reinforce democracy and make governance cost effective and efficient (Dare and Venot 2018).

Multilateral organisations including the World Bank has consistently call for decentralised governance in the areas of health care, education and natural resource management in less developed countries owing to the benefits of decentralisation (World Bank 2004). Nevertheless, numerous stakeholders comprising water user groups at the community levels often do not have adequate funding and institutional competence to significantly contribute to the management of community level water resource systems (Acheampong 2011; Knüppea and Meissner 2016; Msuya and Lalika 2018). The lack of funding and institutional competence has been identified as a major setback to the decentralisation concept and has significantly affected local level water management. In addressing these challenges, the World Bank has proposed various mechanisms for water management that are geared towards achieving sustainable water supply in rural communities. These key principles and policy prescriptions include privatisation, decentralisation, effective law enforcement and monitoring (World Bank 1993).

The concept of privatisation has been advocated strongly whenever resources are owned in common as the only way to prevent the tragedy of the commons (Rusca and Schwartz 2018; Johnson 1972). Wong (2007) suggest that deregulation and privatisation of water resources are an important part of water reform policies that could induce water supply sustainability. Primarily, privatisation redefines water ownership and control, which leads to a significant reduction of government control in water management (Wong 2007; World Bank 2004). Similarly, Marin (2009) advocates for private sector participation in water management and argue that privatisation has significantly improved utilities in the areas of efficiency and service quality. Privatisation again has led to increased investment and contributed to expanding access to water resources (Wong 2007; Marin 2009). On the contrary, Balland and Platteau (1996) and Ostrom (1990) described water privatisation as a misguided policy. Beck and Nesmith (2000) pointed out that privatising local resources has led to the elimination of the poor and disadvantaged people's access to common resources and undermined traditional and local practices of water resources management, which has affected sustainable water supply adversely. Hauter (2011) asserted that countries such as Japan, Canada, Egypt and some Scandinavian countries, have been experiencing sustainable water supply without water privatisation. Conceptually, community participation typifies a bottom up approach because community members are urged to take part in decision-making that affect their existence (Dare and Venot 2018; Franzén et al. 2015). It has been noted that implementing decentralisation and privatisation promote competition and therefore provide better services. These concepts form the essential part of water reforms aimed at providing sustainable water supply (Marin 2009; Wong 2007).

In addition, monitoring and enforcement mechanisms have also been noted as central to ensuring sustainable water supply in communities and clearly defined rules specifying desirable water usage behaviour and sanctions meted out to people who fail to abide by the set rules and regulations (Okpara et al. 2018; Franzen et al. 2015; Cleaver et al. 2005). Ostrom (1992) attributed the inability to realise better water management to ineffective and inefficient 
governance, regulatory and legal arrangements. Indeed, due to the complex nature of water resources, the market alone may lack the ability to realise both water efficiency and equity at the same time. Therefore, community participation in water resource management is offered as an essential conduit to achieving sustainable water supply in Ghana.

\section{Methodology}

\subsection{Study design}

This study employed a multiple methods study design. These include the collection of data using household survey questionnaire and in-depth face-to-face interviews. Bongo District is located in the Upper East Region of Ghana and is one of nine districts in the region. Bongo Township is the district capital and shares borders with Burkina Faso to the north and east, Kassena-Nankana district in the West and Bolgatanga Municipality in the south. The district for some time now has been saddled with various difficulties related to water - high concentration of fluoride content in drinking water, unsafe and inadequate water supply systems. According to Ghana Health Service (1995), about 33\% of school going children suffer from dental fluorosis attributed to the water available in the study area. The Ghana Statistical Service (2010) put the population of the district at 84,545 persons. In terms of water sources, boreholes and hand dug wells are the two main sources of potable water for people in the district. Out of the 335 boreholes constructed by different interest groups, 23 have been nonfunctional for many years. However, due to high fluoride content in the area, only 35 boreholes have been capped as part of the measures to address high fluoride content in the water. The total number of functional boreholes in the district sits at 275 as at the time of the fieldwork. Besides the boreholes, there are 240 hand dug wells in the district. Out of these number, about 150 have been provided with pumps, which forms part of the mechanisation of the water supply systems with support from civil society organisations (NGOs). Figure 2 presents a map of the study area.
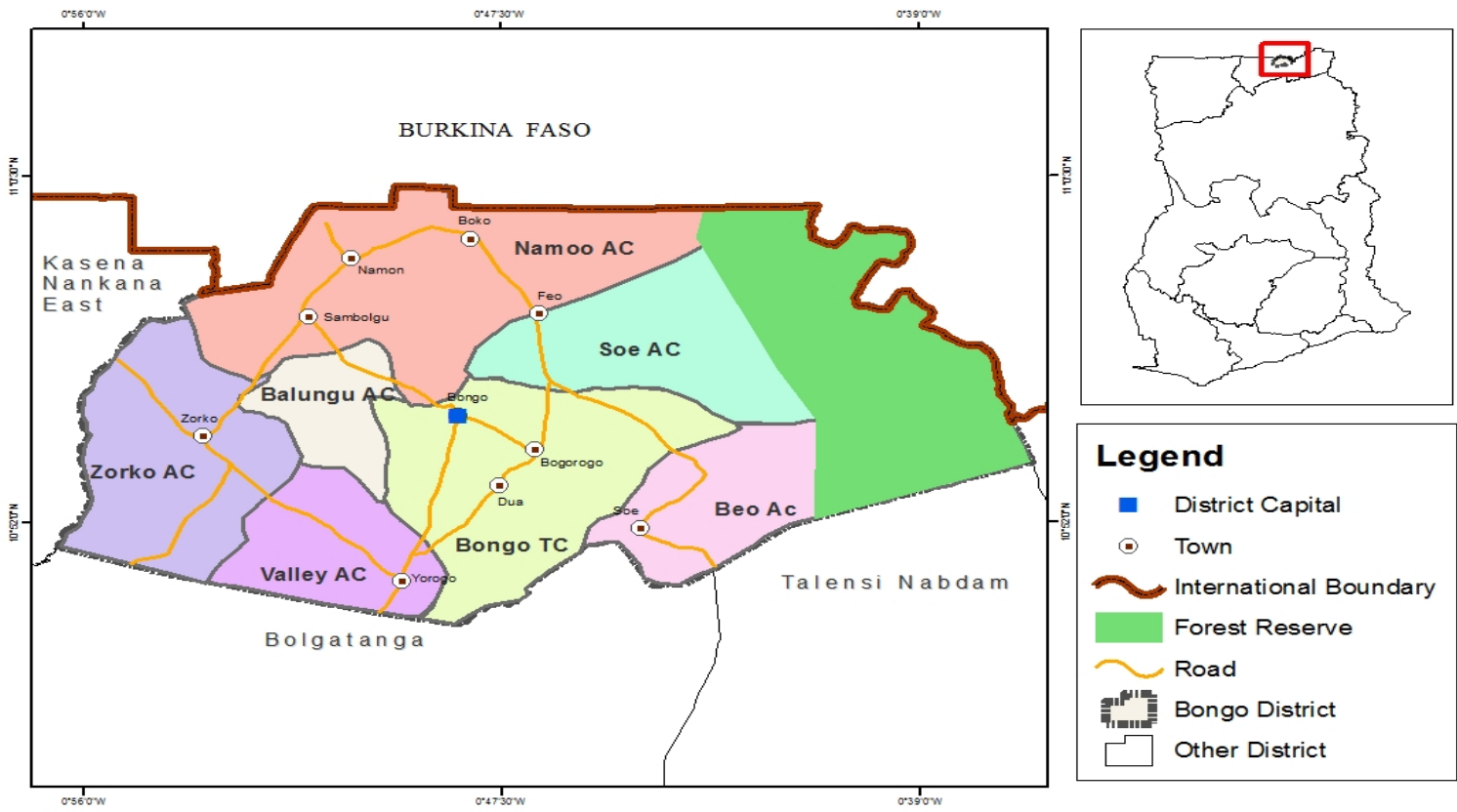


\section{Figure 1: Map of Bongo}

Source: IHDR/JICA, 2005

\subsection{Sample selection}

The bongo district has seven major political and administrative divisions termed area councils and further divided into eighty-one communities of which twenty-four communities were selected for this study. First of all, the stratified sampling method was employed based on the seven major political and administrative area council categorisation. These major divisions include Bongo, Balungo, Namoo, Soe, Valley Zone and Zorko. Therefore, this sampling method was appropriate in selecting the study areas along these political and administrative divisions and also to ensure fair representation. The quota sampling method was then applied to select the sampled communities to carry out the study based on the seven administrative divisions of the district in order to ensure equal representativeness as well. Hence, the study covers 30 per cent of the area representing twenty-four communities as shown in table 1.

Table 1: Selected communities for the study

\begin{tabular}{lcc}
\hline Area council & No. of communities & Sample selected \\
\hline Balungo & 6 & 2 \\
Bongo & 10 & 3 \\
Namoo & 9 & 3 \\
Soe & 19 & 6 \\
Valley zone & 21 & 6 \\
Zorko & 8 & 2 \\
Beo & 8 & 2 \\
\hline Total & 81 & 24 \\
\hline
\end{tabular}

After selecting the sample size of twenty-four communities, the next step was to identify the particular communities within the political and administrative zones that the study was to be conducted. In doing so, a sample frame was applied detailing a list of all eighty-one communities categorised under the major divisions. In selecting the twenty-four communities from the sample frame, the systematic sampling technique was used. For instance, in selecting the three communities from the Bongo township, a sample fraction was determined using the formula $\mathrm{N} / \mathrm{n}=\mathrm{K}$ where, $\mathrm{N}=$ Number of communities, $\mathrm{K}=$ sample fraction, $\mathrm{n}$ = selected sample from sample frame that is $10 / 3=3.3 \approx 3$, and $k=3$. Hence, the sample fraction was three. The selection of the first community was done randomly between 0 and 3 using table of random numbers. Once the first community was randomly selected, every $3^{\text {rd }}$ community from the list was selected. The same procedure was followed for the selection of communities from the rest of the divisions in the district for the study. In each community, the primary units selected and interviewed were chiefs and opinion leaders; assembly members; women group leaders; and WATSAN Committee members. Whereas at the district and regional levels, we interviewed water and sanitation team members; members of the department of community water; and an official from Rural Aid, a non-governmental organization. The key participants were purposively selected due to their information potential and their active involvement in community water management systems in the district and the region as whole. The major beneficiaries of water resources were represented by households, these participant formed the main information source for the utilisation of the cross-sectional household survey. We applied the quota sampling technique to administer the household survey questionnaire. This resulted in the selection of five households in each of the twenty-four selected communities. The total 
number of respondents for the household survey was 120 . The total study sample size for both the cross-sectional household survey and the face-to-face interviews with key informants were 167 respondents.

\subsection{Data collection}

The cross-sectional household survey and the face-to-face interviews were conducted concurrently by the research team members. One team member conducted the face-to-face interviews and the other team member administered the household survey, which comprised of a set of standardised questions. The questionnaire were personally distributed to the communities due to the high rate of illiteracy in the northern part of the country. Even though, the questions were designed in English, the researchers translated the questions into the local language during the interview sessions and based on the responses provided by the respondents, the researchers filled in the questionnaire. This approach was to avoid back translation which may lead to loss of important content. Moreover, this data collection approach also contributed to the high response rate. The research team members have good working understanding of the local language. In relation to the interviews, both English and the local language were utilised, the face-to-face interviews with the chiefs, opinion leaders, women group leaders and WATSAN committee members were all conducted in the local language, whereas, English was the language of communication with key stakeholders including assembly members, sanitation team members at the district and regional office, members of the department of community water and officials from Rural Aid. The interviews lasted between 40-50 munities each. All the interviews were audio recorded and transcribed. Table 2 provide detail characteristics of participants involved in the face-to-face interviews.

Table 2: Characteristics of participants interviewed $(N=47)$

\section{Community-level participants:}

Fourteen (14) chiefs and opinion leaders

Eleven (11) assembly members

Nine (9) Women group leaders

Eight (8) WATSAN Committee members

\section{District and regional level participants:}

Three (3) sanitation team members

One (1) member of the department of community water

One (1) official from Rural Aid

\subsection{Data analysis}

We utilised two different data analysis techniques due to the use of household survey data and face-to-face interview data. The household survey data was analysed using Statistical Package for Social Sciences (SPSS) to generate tables, frequencies and percentages. Whereas, the faceto-face interviews data, was coded into excel based on thematic analysis techniques. These resulted in the generation of several themes.

\section{Findings and discussions}

\section{Demographic characteristics}

The demographic characteristics of respondents suggest that female (65.5\%) participation in the household survey outnumbered their male counterparts (35.5\%).This was not surprising because women constitute the major users of water resources at the household levels. This 
results when compared to the national distribution of household head representations of males (66.4\%) to females (33.6\%) (Ghana Statistical Service 2010) showed that the distribution in the Bongo district is the reverse of the national pattern. This may reflect the fact that in Ghana women are responsible for household water management and represent key stakeholders in water resource management at the household level. The main economic livelihood for the study participants is farming and animal rearing, while shea nuts picking is a common activity for women in the area.

\section{Sources of water supply}

The main sources of water found during the study throughout the entire district were boreholes and hand dug wells. We found only a few (less than $2 \%$ ) people in the Bongo central township and Vea have access to pipe-born water occasionally, while a section of the Akansiringa community in the Soe zone also resorted to dug outs well for their source of water. Provision of water in the district is still a major issue that policy-makers will have to deal with as a significant proportion of the population still do not have access to portable water. Quite a huge number (27\% of respondents) of participants admitted they do not have a clean source of portable water. The study observed that some water sources, especially from wells and dug outs had some tiny living organisms, which the authorities treat once a while to ensure purity. This is very worrying as $31 \%$ of the participants indicated that they suffer from various water-related diseases such as typhoid, diarrhoea, cholera as well as dental fluorosis deformities, stomach upsets and skin disorders from the use of such water sources in the district. Children were the most affected cohort in relation to the effect of water-borne diseases in the communities. Primarily, dental fluorosis is a major problem which affects the self-esteem of people living in such communities. Many Ghanaians view people with dental fluorosis as a sign of dirtiness which implicitly or explicitly affect their self-esteem in society. Thus, the challenges with access to portable water supply does not only affect household activities but largely have a serious perpetual psyche-social effect on the people in the district and limit their chances of getting married outside the community because of the issue of dental fluorosis. The inadequate water supply systems in the communities account for the excessive pressure on few existing and functional water systems. As a result, the vulnerability of women and children is worsened as they have to travel long distance in search of water for the household.

\section{Nature of community participation in water management}

To understand participation at the community level, the study examined decision-making, rule formulation and general water resource management practices. Participation as the respondents indicated was in twofold (community meetings and consultation). During community meetings on water management, variety of issues such as fixing levies, pump maintenance, formulation of rules, day-to-day management of water systems inter alia are tabled for discussion. The study noted that community involvement in water resource management to a certain extent improved the inclusion of excluded groups such as women and children. In fact, the participation of women in water resource management was observed to be enormous, which is consistent with findings from the World Bank (1993) that women are important stakeholders in water resource management at the community and the need to be included in the decision-making process at the local level. The nature of participation in the communities was described as diverse because it encompasses all kinds of people and groups at the community level. They include among others women, elderly and opinion leaders as well as the youth contrary to the general assertion that women are underrepresented in natural resource management and that water resource management teams are simply male dominated social clubs (Zwarteveen, 1997; Adams et al., 
2018). This study also provide evidence to suggest that women were very much represented and instrumental in water systems management teams in all the communities.

\section{Community level mechanisms and strategies for sustainable water supply}

\section{Rules and regulations in water systems management at the community level}

With regards to water systems management at the community level, various rules and regulations were put in place across the entire district to ensure sustainable supply of water. It was found that beneficiaries were mandated to join queues to draw one basin of water at a time. This was meant to prevent unnecessary disagreements (confrontations among community members) that could lead to conflict. Also participants were not allowed to draw water late in the night as part of the measures to ensure sustainability. The assertion was that drawing water at night may lead to unregulated use and subsequent breakdown of water systems, combined with the lack of supervision and monitoring mechanisms in the night. Furthermore, avoiding littering the surroundings and not wearing slippers up the pump stand will keep the system clean, which is very necessary in prolonging the life-span of the water systems. Beneficiaries were mandated to honour their financial contributions for maintenance and operation purposes as well as avoid the sale of water. In addition, strongly banging the pump handle was also not allowed because this could easily cause it to break. Aside the general rules, it was also observed that all participants across the entire district had specific measures in their various homes to ensure the proper management of water. Among them include separating drinking water from other purposes and preventing children from having access to stored water in the house in order to ensure that there is no wastage as it was the view of most parents that children were the most culpable. Fundamentally, all these informal rules were to ensure the sustainability of the water system in the communities. It is obvious that the general rules and regulations prevailing in managing the water systems were very much in place to ensure sustainable supply of water. Interestingly, these informal rules and regulations were not enforced strictly in the district. Indeed, about $94.2 \%$ of respondents opined that they are not punished in any way even though they sometimes acted contrary to the rules and regulations. Some of the respondents attributed the lack of compliance to human error and the lack of law enforcement leading to the emergence of such inappropriate behaviours.

\section{Existence of traditional or social norms}

Traditional norms and practices are touted by institutional and cultural theorists as very effective in managing common pool resources as well as water resource conservation in culturally embedded societies (Osei-Tutu 2017; Nukunya 2003; Frederickson 1999). The use of traditional norms such as "taboos" in most African societies as avenues for social control were very effective in the early ages and the late 1980s (Gondo et al. 2018; Osei-Tutu 2017). However, colonisation, Christianity and formal education are attributed to have contributed significantly to the demise of traditional norms (taboos) and their ineffectiveness as social control systems in Ghana and generally in Africa. Primarily, about $81.7 \%$ of respondents alluded to the fact that traditional norms and taboos are outmoded and are less effective in regulating the behaviour of people towards sustainable water management in the district. For example, the main traditional norm that regulates water usage in the past (1980s) was the fact that it was a "taboo" to draw water in the night (Osei-Tutu 2017). Thus, the indigenes were not allowed to go to water bodies (rivers, boreholes, hand dug wells etc.) late in the night to draw water. The belief was that the gods and ancestors go to water bodies at those times to drink water so attending to water bodies late in the night, one is most likely to meet the gods and the punishment for this include death, terrible sickness or curse by the gods and this was really 
effective in regulating natural resource usage, particularly water. This approach has been discredited by many community members owing to the emergence of civilisation, Christianity and formal education in Ghana. The evidence points to that fact that the efficacies of taboos and some traditional norms that were supportive in regulating natural resource usage in the 1980s in Ghana now remains questionable.

\section{Monitoring and supervision}

In water resource management, monitoring is one of the underpinning principles for achieving sustainable water supply (Franzen et al. 2015; Ostrom 1994). The majority of members frequently involved in water management at the district and community levels asserted that monitoring is carried out at the community level, where water systems are located. Indeed, $80.8 \%$ of the total respondents agreed that the committees responsible for the management and maintenance of the water supply systems at the community levels frequently perform their monitoring and supervision functions. The committees are tasked to inspect the surrounding of the water supply systems, organise clean-up exercises as well as undertake minor repairs and maintenance works. The other strategy devised by the community to ensure effective monitoring is by entrusting the daily care of the water supply systems in the hands of households close to the water supply systems. For example, an elderly person from each household is tasked with an oversight responsibility of each water system. This strategy is to ensure frequent and easy surveillance of the water supply systems. Generally, every community member, especially elders and opinion leaders has a moral and social obligation to perform this monitoring function in order to ensure sustainable water supply in the community.

\section{Imposition of sanctions}

Imposition of sanctions have been noted in the literature to be an effective strategy to deploy for the management of water resources in rural communities (Franks and Cleaver 2005). It has been advocated that sanctions deter free riding behaviour of beneficiaries of common pool resources (Schlager 1994; Ostrom 1994). However, the evidence in this study rather points to the fact that beneficiaries of water resources in the district are not sanctioned for acting contrary to rules and regulations governing water management at the community levels. Even though community management members confirmed that some sanctions include warning for first time offenders, fines, cleaning the surrounding of the water system and in rare cases, some members might be prevented from drawing water. They attributed the inability to sanction offenders to family and community cohesion (solidarity), where people view each person as relatives or one family. The culture of collectiveness makes it extremely challenging to enforce formal rules and regulations at the community level. It was therefore not surprising to find that $94.2 \%$ of the respondents asserted, they may not be sanctioned for going contrary to the rules and regulations governing water resource management. This finding is in line with arguments put forward by cultural theorists (Nukunya 2003) that countries with a collectivist cultural orientation, individuals are inclined to protect one another as people view such acts as a moral and social obligation within the spirit of familiness. This also reflect the African concept of "Ubuntu" interpreted as 'humanness' which denote respect, human dignity, humility, collective sharedness, hospitality, communism and solidarity (Ayentimi et al. 2018; Matolino and Kwindingwi 2013).

\section{Ownership of water systems}

This is the mechanism that seeks to entrust the entire management of the water supply systems into the hands of beneficiaries after its commissioning. In this case, the beneficiaries feel part and own the system and the process of decision-making regarding the management of the 
system. At the community level, the sense of ownership have been instilled into beneficiaries of water resource systems via their engagement and involvement in decision-making and management of the water supply systems. The study found that community members were solely responsible for the management and control of the water supply systems after construction. The role of the government via the district assembly was limited to only construction and the rest of the activities are sponsored and undertaken by the community members, this demonstrate a strong sense of ownership in water resource management at the community level. It was also found that in some cases, community members have to use alternative means to get support from NGOs and individual philanthropists to support them in the construction of some water supply systems as government alone could not shoulder all the responsibility. Thus, the provision and maintenance of water supply systems in the district is seen as a collective responsibility and not a sole responsibility of the local government as might be the case in other societies. Occasionally, beneficiaries also gather stones around the water supply systems to prevent erosion and growth of grass, this was observed in all the communities. Also in some cases community elders provide land for construction of water systems without compensation. All these efforts according to the respondents or participants helped to ensure sustainable clean water supply for all indigenes in the various communities.

\section{Established bodies of addressing indigenes' concerns}

We found that $65.8 \%$ of respondents indicated that aside community leaders and assembly members, the water management committee members were readily available to support the communities address the numerous water challenges. The committee members were elected by the community and they comprise men and women and in some cases auto-mechanics with good background in borehole repairs. Occasionally, community meetings are held to solicit financial support from community members towards the maintenance of the various water supply systems. All these steps and mechanisms employed at the community level are meant to ensure proper and sustainable usage and management of the water supply systems. This evidence further demonstrate the sense of ownership in water resource management at the community level.

\section{Funding mechanisms for operation and maintenance of water resource system}

Funds for the operation and maintenance of the water supply systems were a major challenge that needs urgent attention in the district. In fact, majority of beneficiaries do not pay anything for drawing water. A significant number (90\%) of respondents asserted that they fail to meet their financial obligations for the maintenance of the water supply systems. During the interview with some committee members and opinion leaders who spearheaded the management of the water supply systems, alluded to the fact that financing of the water supply systems were grossly insufficient. As a result, regular maintenance of the systems has become a major problem, which account for the high percentage of frequent breakdowns of the water systems in the communities. Nonetheless, households do occasionally contribute for repair works and maintenance of the water supply systems. The amount varies from community to community and largely depends on the particular purpose to be carried out and the extent of damage. These financial contributions are most often determined by all community members during emergency meetings or consultations.

\section{Policy implications}

The magnitude of the global sustainable water supply challenge, especially in less developed countries across Africa cannot be underestimated and as such significant progress has to be 
made towards the fight against unsafe water supply as over 1 billion people continuously depend on unapproved sources for drinking water (WHO, 2010). The water problem is affecting the lives of people in several communities across the entire district. There is therefore the need for important and effective efforts to find appropriate technical, economic, and communityscale solutions to those problems, especially in rural Ghana. During our field work, we observed acute shortage of water supply and the existence of unapproved sources of water supply systems in the area contributing to water-related diseases and deformities such as: typhoid, diarrhoea, cholera and dental fluorosis. Indeed, waterborne diseases have been linked to significant disease burden in the district. For example, diarrhoeal diseases are responsible for many deaths each year. Importantly, proper household water and sanitation practices can increase resilience to waterborne disease risks in the district. These practical measures may include safe water piping materials and storage, education on hygienic behaviours and sanitary sewage disposal. Additionally, water conservation measures and energy-efficient water infrastructure can also support in lessening the burden of waterborne diseases in the district.

It is important to further acknowledge that the challenges with access to portable water supply does not only affect household activities but largely have a serious perpetual psyche-social effect as well as social-esteem on the people in the district and limit their chances of getting married outside the community because of the issue of dental fluorosis. Again the issue of free riding among some members was prevalent, this therefore requires a more appropriate strategy to address the issues of free riding to support the sustainability of the water supply systems in the area. An 'adaptive management' approach instead of an 'anticipatory' strategy is offered as an appropriate alternative for most water management actions at the community level (Opare 2011; Adams et al. 2018). Therefore, an effective water management system should depend largely on a proper functioning institutional framework with support from key stakeholders, especially the local government (Cavalcanti et al. 2013; Kujinga 2002). Finally, we contend that a more community oriented management approach is needed to ensure sustainable water supply. A community-focused water management system should acknowledge stakeholder participation, community ownership, monitoring and enforcement of local regulations and community level funding support. This local level strategy has been partially effective in the management of the water supply system in local communities. Thus, a more holistic community water management approach is called for with support from the local government to ensure the sustainability of water supply systems in rural Ghana.

\section{Conclusion}

The provision of portable water for the people in the Bongo district is still a major problem as the indigenes allude to limited support and effort on the part of the government in providing portable water supply. As a result, the vulnerability of women and children is worsened as they have to travel long distance in search of water. The inadequate water resource systems in the communities account for the excessive pressure on few existing and functional water systems. This situation contributes to the frequent breakdown of water systems in the communities. Appropriate measures and practices put in place by community members were meant to ensure sustainable management of water supply, but the lack of sustainable funding sources were undermining such efforts. The impact of the water management committees (WMC) in ensuring sustainable supply of water in the communities was positive. As a result, there was the sense of ownership instilled in community members who tend to be fully involved and engaged in the entire decision-making process that ensured sustainable water supply. However, formulation of rules and regulations by the WMC and community members were not effective in the management of water resource systems. The lack of effectiveness in the management was 
attributed to the failure to punish community members who go contrary to laid down rules and regulations due to community solidarity and cohesion which is typical of any African society. The absence of sanctions meted out to community members who violated rules and regulations governing water systems nurtured the problem of "free riding" in the communities and contributed to the frequent break down of the water supply systems. The concept of participation in water resource management at the community level is mainly in decisionmaking, rule formulation and general day-to-day management of the water systems. The evidence points to grass root participation with diverse representation through a democratic process. This situation improved the plight of excluded groups, especially women who were adequately represented in the decision-making process. Most importantly, funding for the maintenance of the water systems were grossly insufficient to ensure sustainable water supply.

\section{References}

Acheampong, S. Y. (2011). Water resources management and water supply in Ghana. Retrieved from

Adams, E. A., Juran, L., \& Ajibade, I. (2018). 'Spaces of Exclusion' in community water governance: A Feminist Political Ecology of gender and participation in Malawi's Urban Water User Associations. Geoforum, doi.org/10.1016/j.geoforum.2018.06.016.

Adams, E. A., \& Smiley, S. L. Urban-rural water access inequalities in Malawi: implications for monitoring the Sustainable Development Goals. Natural Resource Forum, doi.org/10.1111/1477-8947.12150.

Ahadzie, G., Gormey, B., Anderson, K., Ahorbo, M., Addo, K. O., \& Abassah, S. D. (2005). Water: the case for conservation. Accra, the Green Earth Organisation.

Alkire, S., \& Deneulin, S. (2000). Individual motivation, its nature, determinants and consequences for within group behaviour. Research Paper 184, World Institute for Development Economics Research.

Apipalakul, C., Wirojangud, W., \& Ngang, T. K. (2015). Development of Community Participation on Water Resource Conflict Management. Procedia - Social and Behavioral Sciences, 186, 325-330.

Ayentimi, D. T., Burgess, J., \& Brown, K. (2018). HRM development in post-colonial societies: The challenges of advancing HRM practices in Ghana. International Journal of Cross Cultural Management, doi.10.1177/1470595818765863

Barley, S. R., \& Tolbert, P. S. (1997). Institutionalization and Structuration: Studying the Links between Action and Institution. Organization Studies, 18(1), 93-117.

Beck, T., \& Nesmith, C. (2000). Building of poor people's capacities: The case of common property resources in India and West Africa. World Development, 29(1), 119-33.

Butterworth, J., Warner, J, Moriarty, P., Smits, S., \& Batchelor, C. (2010). Finding practical approaches to Integrated Water Resources Management. Water Alternatives, 3(1), 6881.

Cavalcanti, C., Engel, S., \& Leibbrandt, A. (2013). Social integration, participation, and community resource management. Journal of Environmental Economics and Management, 65, 262-276.

Cleaver, F. (2002). Reinventing institutions: Bricolage and the social embeddedness of natural resource management. The European Journal of Development Research, 14(2), 11-30.

Cleaver, F., Franks, T., Boesten, J., \& Kiire, A. (2005). Water governance and poverty: What works for the poor? Bradford Centre for International Development. 
Community Water and Sanitation Agency. (2009). Water and sanitation sector performance report. Accra, MWRWH.

Dare, W., \& Venot, J-P. (2018). Room for manoeuvre: User participation in water resources management in Burkina Faso. Development Policy Review, 36(2), 175-189.

Distanont, A., Khongmalai, O., Rassameethes, R., \& Distanont, S. (2017). Collaborative triangle for effective community water resource management in Thailand. Kasetsart Journal of Social Sciences, doi.org/10.1016/j.kjss.2017.07.015.

Foli, S., Ros-Tonen, M. A. F., Reed, J., \& Sunderland, T. (2018). Natural Resource Management Schemes as Entry Points for Integrated Landscape Approaches: Evidence from Ghana and Burkina Faso. Environmental Management, 62, 82-97.

Fonjong, L. N. Emmanuel, N. N., \& Fonchingong, C. C. (2004). Rethinking the Contribution of Indigenous Management in Small-Scale Water Provision among Selected Rural Communities in Cameroon. Environment, Development and Sustainability, 6, 429-451.

Franzén, F., Hammer, M., \& Balfors, B. (2015). Institutional development for stakeholder participation in local water management-An analysis of two Swedish catchments. Land Use Policy, 43, 217-227.

Frederickson, H. G. (1999). The repositioning of American public administration. Political Science and Politics, 32(2), 701-711.

Ghana Statistical Service. (2010). Ghana Living Standards Survey. Report of the fourth round (GLSS 4). Accra, Ghana Statistical Service.

Giddens, A. (1984). The constitution of society. Berkely, University of California Press.

Gondo, R., Kolawole, O. D., \& Mbaiwa, J. E. (2018). Dissonance in customary and statutory water management institutions: issues of cultural diversity in the management of water resources in the Okavango Delta, Botswana. Environment, Development and Sustainability. doi.org/10.1007/s10668-018-0093-3.

Harvey, P. A., \& Reed, R. A. (2007). Community-managed water supplies in Africa: sustainable or dispensable? Community Development Journal, 42(3), 365-378.

Hauter, W. (2011). Victory in Italian referendum an inspiration for water justice movements, food \& water watch. http://www.foodandwaterwatch.org/pressreleases/victory-initalian-referendum-an-inspiration-for-water-justice-movements. Accessed June 5, 2011.

International Water and Sanitation Center. (1993). The role of communities in the management of improved water supply systems. Occasional paper 20. www.irc.nl/content/download/2559/26363/file/op20e.pdf. Accessed 20 April, 2013.

Johnson, O. (1972). Economic analysis, the legal framework and land tenure systems. Journal of law and economics, 15(1), 259-276.

Kelly, E., Lee, K., Shields, K.F., Cronk, R., Behnke, N., Klug, T., \& Bartram, J. (2017). The role of social capital and sense of ownership in rural community-managed water systems: Qualitative evidence from, Ghana, Kenya and Zambia. Journal of Rural Studies, 56, 56-166.

Kim, J. H., Keane, T. D., \& Bernard, E. A. (2015). Fragmented local governance and water resource management outcomes. Journal of Environmental Management, 150, 378-386

Kujinga, K. (2002). Decentralizing water management: an analysis of stakeholder participation in the management of water in Odzi subcatchment area, Save Catchment. Physics and Chemistry of the Earth, 27, 897-905.

Marin, P. (2009). Public-private partnerships for urban water utilities: a review of experiences in developing countries, Public-Private Infrastructure Advisory Facility, World Bank Overview, pp. 6-7.

Matolino, B., \& Kwindingwi, W. (2013). The end of Ubuntu. South African Journal of Philosophy, 32(2), 197-205. 
Msuya, T. S., \& Lalika, M. C. S. (2018). Linking Ecohydrology and Integrated Water Resources Management: Institutional challenges for water management in the Pangani Basin, Tanzania. Ecohydrology \& Hydrobiology, 18, 174-191

Nastar, M., Abbas, S., Rivero, C. A., Jenkins, S., \& Kooy, M. (2018). The emancipatory promise of participatory water governance for the urban poor: Reflections on the transition management approach in the cities of Dodowa, Ghana and Arusha, Tanzania. African Studies, doi:10.1080/00020184.2018.1459287.

Nukunya, G. K. (2003). Tradition and change in Ghana: an introduction to sociology (2 ed). Accra, Ghana: Ghana Universities Press.

Okpara, U. T., Stringer, L. C., \& Dougill, A. J. (2018). Integrating climate adaptation, water governance and conflict management policies in lake riparian zones: Insights from African drylands. Environmental Science and Policy Journal, 79, 36-44.

Opare, S. (2011). Sustaining water supply through a phased community management approach: lessons from Ghana’s “oats” water supply scheme. Environment, Development and Sustainability, 13, 1021-1042.

Osei-Tutu, P. (2017). Taboos as informal institutions of local resource management in Ghana: Why they are complied with or not. Forest Policy and Economics, 85(1), 114-123.

Ostrom, E. (1990). Governing the commons: The evolution of institutions for collective actions. New York, Cambridge University Press

Ostrom, E. (1992). Crafting institutions for self-governing irrigation systems. San Francisco, CA, ICS Press.

Ostrom, E. (1994).Governing the commons: The evolution of institutions for collective action. Cambridge University Press, New York.

Ostrom, E. (2005). Understanding institutional diversity. New Jersey, Princeton University.

Rahm, D., Swatuk, L., \& Matheny, E. (2006). Water Resource Management in Botswana: Balancing Sustainability and Economic Development. Environment, Development and Sustainability, 8, 157-183.

Rusca, M., \& Schwartz, K. (2018). The paradox of cost recovery in heterogeneous municipal water supply systems: Ensuring inclusiveness or exacerbating inequalities? Habitat International, 73, 101-108.

Schlager, E. (1994). Fishers' institutional responses to the common - pool resources dilemmas. Rules, Games and common pool resources, (Ed) Ostrom, Gadner and Walker, Ann Arbor. University of Michigan Press. pp. 247-66.

Tantoh, H. B., \& Simatele, D. (2018). Complexity and uncertainty in water resource governance in Northwest Cameroon: Reconnoitring the challenges and potential of communitybased water resource management. Land Use Policy, 75, 237-251.

UNDP. (2007). Ghana Human Development Report 2007. Towards a more inclusive society. Accra, Ghana.

Water and Sanitation Sector Monitoring Platform. (2010). Status of Ghana's drinking water and sanitation sector. www.wsmp.org. Accessed 30, January, 2014.

Water Research Institute, Centre for Scientific and Industrial Research. (2010). WRI predicts water deficit in 15 years. The Daily Graphic, November 18, 2010 issue.

WHO \& UNICEF. (2010). Progress on sanitation and drinking water. New York, WHO Press.

Wong, S. (2007). Building a sustainable water framework with a human face. Sustainability Research Institute (SRI) Papers. United Kingdom, SRI.

World Bank. (1993). Water resources management policy paper. World Bank, Washington D.C.

World Bank. (2004). Water resources sector strategy: Strategic directions for World Bank engagement. World Bank, Washington D.C. 
World Water Council. (2003). IWRM and the basin management theme. Draft statement. $3^{\text {rd }}$ World Water Forum, Japan. http:/www.riob.org/IMG/pdf/iwrm_basin.pdf. Accessed 15, January, 2013.

Yeleliere, E., Cobbina, S. J., \& Duwiejuah, A. B. (2018). Review of Ghana's water resources: the quality and management with particular focus on freshwater resources. Applied Water Science, 8: 93. doi.org/10.1007/s13201-018-0736-4

Zwarteveen, M. (1997). Water: from basic need to commodity: a discussion on gender and water rights in the context of irrigation, World Development, 25(8), 1335-1349. 